\title{
Criminal Liability against Children as Perpetrators of Theft
}

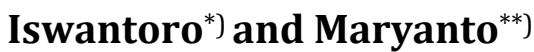

*) Student of Master of Law, Faculty of Law, Universitas Islam Sultan Agung (UNISSULA) Semarang, E-mail: billykayen@gmail.com

${ }^{* *}$ Lecturer of Master of Law, Faculty of Law, Universitas Islam Sultan Agung (UNISSULA) Semarang

\begin{abstract}
.
The objectives of this study are: 1. To analyze criminal responsibility towards children as perpetrators of criminal acts of theft in the jurisdiction of the Pati District Court. 2. To analyze constraints in the implementation of criminal responsibility against children as perpetrators of criminal acts of theft in the jurisdiction of the Pati District Court and their solutions. The research method used is juridical empirical. Research results and discussion The background of the crime of theft committed by children is various factors, including; lack of parental attention and supervision. The occurrence of the criminal act of theft, not only raises legal problems but also creates economic problems and social problems in the community, because it is an act that is detrimental to the state and to this act the state reacts with punishment as the last resort (Ultimum Remedium)Accountability for the verdict of case Number: 5 / Pid.Sus-Anak / 2017 / PN Pati, with the defendant WES Known as Wn Bin S having been legally and convincingly proven guilty of committing the crime of "Theft in Aggravating Circumstances"; as regulated and punishable under Article 363 paragraph (1) 4 of the Criminal Code as in the single indictment, imposes a crime against the child of WES Known as $W$ Bin $S$, in the form of imprisonment for 7 (seven) months at the LPKA (Special Development Institution for Children), arrest and detention that has been served by the child is fully deducted from the sentence imposed, so that the child remains detained, by charging the child a case fee of IDR 2,500 (two thousand and five hundred rupiah).

Keywords: Criminal; Liability; Children; Theft.
\end{abstract}

\section{Introduction}

Children as the younger generation are the potential and successor to the ideals of the nation's struggle. Children are development assets that will maintain, maintain, and develop existing development results. Therefore, children need protection in order to ensure complete, harmonious and balanced physical, mental and social growth and development.

In maintaining harmony in life in society, various kinds of rules are needed as guidelines in maintaining and regulating the relationship between individual interests and the interests of the general public. ${ }^{1}$ Legislation which is expected to be able to balance the various needs and interests of each person who is different and even contradicting each other and in the end can create security and order in society.

However, in reality, the life order that has been regulated in various laws and regulations is still violated, it is proven that there are many criminal cases that

${ }^{1}$ http://ditjenpp.kemenkumham.go.id/htn-dan-puu/232-proses-pengharmonisasian-sebagaiusaha-men Increase-k Quality-peraturan-perundang-undangan.html Accessed on 15 November 2019 
have occurred, even though government officials have carried out mental development for the community in various ways, which are expected to be able to minimize the occurrence of legal violations in society. .

Deviated behavior or illegal acts committed by society are caused by various factors, including the negative impact of rapid development, the flow of globalization, advances in communication and information, advances in science and technology and changes in lifestyle and ways of some people bring about fundamental changes in people's lives. ${ }^{2}$

For example, criminal acts of theft, especially those committed by children, are certainly motivated by various factors, among others; lack of parental attention and supervision ${ }^{3}$. The occurrence of the criminal act of theft, not only raises legal problems but also creates economic problems and social problems in the community, because it is an act that is detrimental to the state and to this act the state reacts with punishment as the last resort (Ultimum Remedium). The evil that was already creeping up among the children. It is not only children who are victims of violence against children, what is most concerning now is that the children themselves are the perpetrators of the crime. ${ }^{4}$

There are so many phenomena reported by the mass media that children become perpetrators of violent theft. Criminal acts committed by children start from the child's deviance from the norms of society which tend to lead to criminal acts or often referred to as Juvenil Deliquency. Child crime (Juvenil Deliquency) is one of the government's urgent problems in tackling criminal acts in Indonesia. Children should be an inseparable part of the survival of humans, the nation and the state.

In the Indonesian constitution, children have a strategic role which explicitly states that the state guarantees the right of every child to live, grow and develop and is entitled to protection from violence and discrimination, as described in the 1945 Constitution Article 28 B paragraph 2. Because children are important elements of the state, then the criminal acts committed by children of the Indonesian constitution form the Act No. 11 of 2012 concerning the Juvenile Criminal Justice System.

Act No. 11 of 2012 concerning the Criminal Justice System for Children affirms the meaning of children in Article 1 Number (3) states that:

"A child in conflict with the law, hereinafter referred to as a child, is a child who has reached the age of 12 (twelve) but has not reached the age of 18 (eighteen) who is suspected of committing a criminal act. The Law on Juvenile Court looks at the child's side of the act he has committed, if the child commits a crime before the child is 12 (twelve) years old, it is not categorized as a delinquent child so that from a legal perspective he cannot be held accountable, on the contrary when he reaches the age of 12 twelve) to 18 (eighteen) years of age can be held accountable for their actions, then if the child is married before the age of 18 (eighteen) then it is not categorized

\footnotetext{
${ }^{2}$ https://lawyersinbali.wordpress.com/2012/01/11/penyviationmelanggar-hukum-teori-aspeksosio-psikologis-dan-faktor-yang-mempentukinya Accessed on November 15, 2019

3 Kusfitono, Umar Ma'ruf, Sri Kusriyah, Implementasi Putusan Mahkamah Konstitusi Nomor 130/PUU-XIII/2015 Terhadap Proses Penyidikan Tindak Pidana Pencurian Dengan Pemberatan Di Sat Reskrim Polres Kendal, Jurnal Hukum Khaira Ummah Vol. 12 No. 4 Desember 2017 : 862-874 ${ }^{4}$ Gultom, Maidin. (2006). Perlindungan Hukum Terhadap Anak. Bandung: Refika Aditama. p. 35
} 
as a child and the judicial process through general court is not juvenile court. "

Children who commit criminal acts in the context of positive criminal law in effect in Indonesia must still be held accountable for their actions, however, considering the perpetrators of criminal acts are still minors, the law enforcement process is carried out specifically. ${ }^{5}$ Examples of cases of theft that have permanent legal force Decision Number: 5 / Pid.Sus-Anak / 2017 / PN Pati, stated that the child of WES Known as W Bin S has been legally and convincingly proven guilty of committing the criminal act "Theft in a burdensome situation"; as regulated and punishable under Article 363 paragraph (1) of the 4th Criminal Code as in the single indictment; Sentenced the child of WES, Known as W Bin Sn, in the form of imprisonment for 7 (seven) months at LPKA (Institute for Special Development for Children),Based on the case, it has been processed and accounted for in accordance with Article 362 (1) the 4 KUHP, and has obtained permanent legal force by the Pati District Court.

\section{Research Methods}

This research uses a sociological juridical approach. Juridical means that in this study emphasizes the applicable legal principles based on the aspects of positive legal regulations. The type / specification of research in this thesis includes descriptive analytical, which describes the applicable laws and regulations in relation to legal theories. Types of data and data sources of this research include primary data and secondary data. Primary legal materials, namely legal materials obtained from legislation. Data collection methods include literature study, observation, interviews. To perpetrators, victims and law enforcers. Data analysis method. The data obtained by qualitative analysis, which means that the results of this study are described in the form of explanations and descriptions of sentences that are easy to read and understand to be interpreted and conclusions can be drawn regarding criminal liability to children as perpetrators of criminal acts of theft.

\section{Results and Discussion}

\subsection{Criminal Accountability Against Children As Perpetrators Of The Crime Of Theft In The Legal Area Of The Pati District Court}

Actions of violence that occur in the community are increasingly troubling. In resolving a conflict or problem accompanied by acts of violence. In general, acts of violence can be defined as the deliberate use of physical force or force, actual threats or violence against oneself, other people, or against a group or community, which results in injury or is likely to injure, kill, harm psychologically, or develop abnormal or loss. ${ }^{6}$ For example, a criminal act of theft where the perpetrator is a

\footnotetext{
5Santoso, Een Indriyanie and Gunarto. Disparitas Pidana Terhadap Perkara Anak ( Studi Kasus Di Pengadilan Negeri Demak), Jurnal Hukum Khaira Ummah Vol. 13. No. March 1, 2018

${ }^{6}$ Aan Hardiansyah, Akhmad Khisni, Jawade Hafidz, Tindak Pidana Kekerasan Dalam Proses Belajar Mengajar Ditinjau Dari Perspektif Hukum Pidana Dan Undang-undang Nomor 14 Tahun 2005 Tentang Guru Dan Dosen , Jurnal Daulat Hukum Vol. 1. No. March 1, 2018 ISSN: 2614-560X
} 
child and does not hesitate to commit crimes, often injuring the victim.

The judicial system is essentially identical to the law enforcement system, because the judicial process is essentially a process of enforcing the law. So, in essence, it is identical with the "judicial power system" because "judicial power" is basically a "power / authority to enforce the law. ${ }^{7}$ The judicial system is seen as an integral part of various sub-systems (components) which consist of components of "legal substance, legal structure and legal culture.

Criminal Accountability Against Children As Perpetrators of The Crime of Theft In The Legal Area Of The Pati District Court. Decision Number: 5 / Pid.SusAnak / 2017 / PN Pati above, the author examines the criminal responsibility theory that: PIn fact, criminal responsibility does not only concern legal matters alone but also concerns moral values or general morals adhered to by a society or groups in society, this is done so that criminal responsibility is fulfilled by fulfilling justice. Criminal liability is a form of determining whether a suspect or defendant is responsible for a criminal act that has occurred.

The concept of criminal liability is the conditions needed to impose a sentence on a criminal act. Determination of criminal responsibility is not only carried out by taking into account the interests of the community, but also the interests of the maker himself. The process depends on the fulfillment of the conditions and conditions for which the perpetrator of the crime can be condemned, so that it is legal if he is convicted.

In other words, criminal liability is a form of determining whether a person is acquitted or convicted. Thus, based on the facts in the trial, the judge has confidence in deciding a criminal case that can provide a sense of justice and the decision can be accepted by the public.

\subsection{Constraints in implementing criminal responsibility against children as perpetrators of Theft crime in the jurisdiction of the Pati District Court and the solutions}

Children who violate the law or commit criminal acts are strongly influenced by several other factors outside of the child such as association, education, playmates and so on, because criminal acts committed by children are generally a process of imitating or being influenced by negative actions from adults or people's surrounding. 8

Inner constraints implementation of criminal responsibility towards children as perpetrators of criminal acts of theft in the jurisdiction of Pati District Court as follows:

a. Children's knowledge of legal issues is still limited. The child's limited knowledge of legal issues causes the child to not know what their rights are, so that the child will be more submissive when examined and often do not understand what he should do and the child will feel very guilty for committing a crime.

\footnotetext{
${ }^{7}$ Warsito, Dafit Supriyanto Daris. Criminal System against Narcotics Abusers, Journal of Daulat Hukum Vol. 1. No. March 1, 2018 ISSN: 2614-560X

8 Ananda, Fiska. Penerapan Diversi Sebagai Upaya Perlindungan Hukum Terhadap Anak Pelaku Tindak Pidana, Jurnal Daulat Hukum Vol. 1. No. March 1, 2018 ISSN: 2614-560X
} 
b. Feelings of fear of facing the law. The second obstacle relates to the discussion of children's limited knowledge. Because children feel afraid and have limited knowledge of legal issues, it causes judges and other law enforcers to have little difficulty in seeking information directly from the child defendant.

c. There is no special room for children. Pati District Court does not have a special courtroom and special cells for children. It is supposed to maximize comfort in children, special courtrooms and special cells are needed, this is so that children do not feel afraid. So, with this convenience, children can follow the course of the judicial process properly and smoothly.

The solution is: According to Satjipto Rahardjo's opinion, to study from the Progressive legal theory is to change rapidly, make fundamental reversals in legal theory and practice, and make various breakthroughs. Liberation is based on the principle that the law is for humans and not the other way around and the law does not exist for itself, but for something broader, namely for human dignity, happiness, welfare, and human glory.

Based on the progressive theory, it is linked to the constraints of implementing criminal responsibility against children as perpetrators of criminal acts of theft, that:

a. Criminalization should be a last resort for children dealing with the law, so the approach to punishment must be different from the current Juvenile Court (Law) which puts forward the retributive justice punishment model. Future laws should prioritize the restorative justice model, namely restoration to its original condition, and punishment as a final way, so other methods outside the court should be prioritized. One of them is by means of diversion, namely the transfer of settlement of juvenile cases from the criminal justice process to processes outside the criminal court.

b. This diversion must be an obligation in handling children in conflict with the law $(\mathrm{ABH})$ in every handling, whether in investigation, prosecution, up to case examination in court.

c. A child who commits a crime / crime (juvenile offender) should not be seen as a criminal (criminal) but must be seen as someone who needs help, understanding and affection;

d. The juridical approach to children should prioritize a persuasive-educative approach which means as far as possible avoiding legal processes that are purely punitive in nature, which are mental degradation and discouragement and avoiding stigmatization processes that can hinder the child's development, maturity and independence process a reasonable sense.

\section{Conclusion}

Accountability for the verdict of case Number: 5 / Pid.Sus-Anak / 2017 / PN Pati, with the defendant Wawan Eko Saputra Known as Wawan Bin Saman having been legally and convincingly proven guilty of committing the crime of "Theft in Aggravating Circumstances"; as regulated and punishable by criminal sanctions in Article 363 paragraph (1) 4 of the Criminal Code as in the single indictment, sentenced the child of Wawan Eko Saputra Known as Wawan Bin Saman in the form of imprisonment for 7 (seven) months in LPKA (Child Special Development 
Institution), The entire period of arrest and detention that has been served by the child is deducted from the sentence imposed, so that the child remains detained, by charging the child to pay a case fee of IDR 2,500 (two thousand and five hundred rupiah)

\section{References}

Journal:

[1] Aan Hardiansyah, Akhmad Khisni, Jawade Hafidz, Tindak Pidana Kekerasan Dalam Proses Belajar Mengajar Ditinjau Dari Perspektif Hukum Pidana Dan Undang-undang Nomor 14 Tahun 2005 Tentang Guru Dan Dosen, Jurnal Daulat Hukum Vol. 1. No. March 1, 2018 ISSN: 2614-560X

[2] Ananda, Fiska. Penerapan Diversi Sebagai Upaya Perlindungan Hukum Terhadap Anak Pelaku Tindak Pidana, Jurnal Daulat Hukum Vol. 1. No. March 1, 2018 ISSN: 2614-560X

[3] Kusfitono, Umar Ma'ruf, Sri Kusriyah, Implementasi Putusan Mahkamah Konstitusi Nomor 130/PUU-XIII/2015 Terhadap Proses Penyidikan Tindak Pidana Pencurian Dengan Pemberatan Di Sat Reskrim Polres Kendal , Jurnal Hukum Khaira Ummah Vol. 12 No. 4 Desember 2017 : 862-874

[4] Santoso, Een Indriyanie and Gunarto. Disparitas Pidana Terhadap Perkara Anak (Studi Kasus Di Pengadilan Negeri Demak ), Jurnal Hukum Khaira Ummah Vol. 13. No. March 1, 2018

[5] Warsito, Dafit Supriyanto Daris. Criminal System against Narcotics Abusers, Journal of Daulat Hukum Vol. 1. No. March 1, 2018 ISSN: 2614-560X

Book:

[1] Gultom, Maidin. (2006). Perlindungan Hukum Terhadap Anak. Bandung: Refika Aditama

Regulations:

[1] Act No. 11 of 2012 concerning the Child Criminal Justice System.

[2] Act No. 8 of 1981 concerning KUHAP (Criminal Procedure Code.

[3] Act No. 39 of 1999 concerning Human Rights.

[4] National Police of the Republic of Indonesia Circular SE / 8 / VII / 2018, Concerning the Application of Restorative Justice in Criminal Case Resolution.

[5] Regulation of the Head of the National Police of the Republic of Indonesia Number 6 of 2019 concerning Criminal Investigation.

Internet:

[1] http://ditjenpp.kemenkumham.go.id/htn-dan-puu/232-prosespengharmonisasian-sebagai-usaha-men Increase-k Quality-peraturanperundang-undangan.html, accessed on 15 November 2019.

[2] https://lawyersinbali.wordpress.com/2012/01/11/penyviationmelanggarhukum-teori-aspek-sosio-psikologis-dan-faktor-yang-mempentukinya.html, Accessed on November 15, 2019 